\title{
Welcoming the "Other": Translating Truth for the Post-truth World
}

\author{
Ovidiu Matiu*
}

This paper is an attempt to answer the question whether Bible translation may help building a community or communities, which would contribute to creating the framework for a commonality of faith. The answer is not difficult to state, since translation is about bridging gaps, about creating communities, as steps forward in this process. It is impossible to understand the process and to formulate an adequate and articulate answer to the initial question without taking a journey through the complex field of Translation Studies, and of Bible translation, in particular. The method of study involves analysis and use of concepts such as the paradox of translation, dynamic equivalence and (essentially) literal translation, in a dialog with authors such as Ricoeur, Berman, Nida or Ryken. This analysis shows that a linguistic oikumene, as a step towards a commonality of faith, is achievable through the translator's hard work of producing linguistic hospitality, as a sine qua non condition for making our home, our language warm enough for the foreigner to dwell in and feel as if he were in his own.

Keywords: language, translation, the Bible, translation process, equivalence, adequacy, the paradox of translation, Erinnerungsarbeit, Trauerarbeit, travail

\section{Translating Truth or the Paradox of Translation}

When it comes to interpreting the Bible, Jacques Derrida is by no means superficial. The Arab-Jew from El-Biar might have had "heretical" approaches, at times, to various biblical episodes, to the history of salvation, in Christian terms, stretching from the Genesis to Saint John's Apocalypse, the tower of Babel included, but he did not fail to understand and make good use of what Yvonne Sherwood calls "quasi-biblical idioms", which "creep into Derrida's acts of writing, as if to mark the haunting of our languages by the Bible". ${ }^{1}$ In terms of understanding the translation process, he was as "orthodox" as one can be: he understood what Ricoeur meant by the paradox of translation, or in other words, the paradox of an equivalence that is never fully adequate.

Ovidiu Matiu, PhD, Assistant Professor, Lucian Blaga University of Sibiu, Romania, Address: Lucian Blaga University, Faculty of Letters and Arts, 5-7 Victorie Blvd., Sibiu 550024, Romania, e-mail: ovidiu.matiu@ulbsibiu.ro.

1 Yvonne Sherwood, "Introduction: Derrida's Bible", in: Yvonne Sherwood (ed.), Derrida's Bible: Reading a Page of Scripture with a Little Help from Derrida, Religion/Culture/Critique, New York, Palgrave Macmillan, 2004, p. 1-20, p. 1. 
In a presentation delivered to the UBS Europe Regional Translation Committee in Rome, in 1982, and then published in Technical Papers for the Bible Translation, Katharina Reiss defines adequacy as simply appropriateness.

[...] Adequacy is thus a relation between means and purpose, and is thereby process-oriented.

Equivalence, on the other hand, is a relation between two products, the source and the receptor texts. A clear distinction must be made between the two terms, because translations may serve different purposes from one another, and a translation may serve a different purpose from its source text. ${ }^{2}$

That is maybe the reason why Derrida used at least two French versions of the Bible "(as if trying to listen as closely as possible through variant translations to the connotations of the Hebrew, Greek, and Aramaic)" ${ }^{\text {, }}$, as if trying to find Eco's "tertium comparationis", written in the perfect language ${ }^{4}$ the only one able to produce the perfect target-language (one could add biblical here) text.

For sure, Derrida's Bible is a fundamentalist's, literalist's Bible for, against all the stereotypes. [...] In his scriptures the transcendental is always held in awkward negotiation with the linguistic material of its production / incarnation: as Derrida's Plato talks in terms of "asses," "blacksmiths," and khôra and pharmakon, so Derrida's Bible speaks in terms of seeds, deserts, bread, and blood as well as messianism and justice-dreams made of "metaphors" straining to transport language beyond itself (metaphorein), trusting to the capacity of language to surpass itself, but also bound over by a sense of the literality and limit of 'so many words'.

What is not, then, Derrida's Bible? If we were to believe Yvonne Sherwood, his Bible is not an improved / new Bible, but a "a rather unfashionably oldnew Bible. [...] a Bible full of marginalia," a Bible which focuses on the "secondary, eccentric, lateral, parasitic" ${ }^{6}$ In other words, it is a Bible whose reading would involve incommensurable work / travail, that type of an effort which Ricoeur defines in psychoanalytic terms.

2 Katharina Reiss, "Adequacy and Equivalence in Translation", in: The Bible Translator, 34 (3/1983, p. 301-308, p. 301.

3 Y. Sherwood, “Introduction: Derrida’s Bible”, p. 1.

4 Magda Jeanrenaud, “Traducerea filozofiei, filozofia traducerii”, in: Paul Ricoeur, Despre traducere, trans. by Magda Jeanrenaud, Iaşi, Polirom 2005, p. 5-41, p. 26.

5 Y. Sherwood, "Introduction: Derrida's Bible", p. 2-3.

6 Ibidem, p. 4. 
It is an effort to accept the paradox of translation (equivalence without adequacy), an effort of acceptance similar to a mourning which has to be consumed. ${ }^{7}$ Ricoeur describes "the difficulties as a wager" as being "accurately summarized in the term 'test' [épreuve], in the double sense of 'ordeal' [peine endurée] and 'probation': testing period, as we say, of a plan, of a desire or perhaps even of an urge, the urge to translate". ${ }^{8}$ According to Ricoeur, the task of the translator (as defined by Walter Benjamin in his The Task of The Translator) should be compared with travail in the Freudian sense: 'work of remembering' / 'work of mourning.' Erinnerungsarbeit and Trauerarbeit translated as work/travail imply both salvaging and loss, in other words "an unparalleled problematic, doubly sanctioned by a vow of faithfulness and a suspicion of betrayal", a paradox which Schleiermacher divides into two distinct tasks: "bringing the reader to the author" and "bringing the author to the reader". The translator's main task in this negotiation is that of the mediator, the go-between whose work (of remembering/mourning) challenges, according to Ricoeur, the reader's belief in the sacredness of the mother tongue. ${ }^{10}$ The reader's resistance to such a violent assault on the mother tongue is the one that materialized in attitudes which could be gathered under the umbrella terms of "linguistic ethnocentrism" and "cultural hegemony". Such attitudes are usually fostered in contexts related to the great empires of all times.

The effort to accept the paradox of translation leaves the translator "in a dissatisfied state", in-between the two forms of resistance (that of the target text and that of the source text). ${ }^{11}$ Ricoeur's solution to this open conflict is linguistic hospitality, a concept which is in complete harmony with Berman's view of translation: "Linguistic hospitality, then, where the pleasure of dwelling in the other's language is balanced by the pleasure of receiving the foreign word at home, in one's own welcoming house". ${ }^{12}$

For both Berman and Ricoeur, "the home" where the former happily receives the latter is the field of translation studies, which gives both of them the possibility to harmonize two (potentially) different perspectives and to declare that neither translation studies, nor hermeneutics should be scientific in the sense in which empirical sciences use the term. They

\footnotetext{
7 M. Jeanrenaud, "Traducerea filozofiei", p. 26.

8 P. Ricoeur, On Translation, trans. by Eileen Brennan, London - New York, Routledge 2006, p. 3.

9 Ibidem, p. 3.

$10 \quad$ Ibidem, p. 4.

11 Ibidem, p. 8.

12 Ibidem, p. 10.
} 
share the idea that reading a text without a detour is impossible in Translation Studies and hermeneutics, and reading with a detour is possible given 'critical' mediation. To approach the original text 'critically' means to read it more consciously and reflectively. A 'correct' translation or interpretation is not possible without reference to other translations and interpretations, and without reference to the inner form and structure of the text at hand. ${ }^{13}$

Thus, welcoming the other involves, actually, welcoming more or all of the others in a continuous dialog, a dialog which requires a perpetual exchange, a "double movement", typical of the romantic literary text, but also "the aim of translation: In the translated text the foreign is certainly made near, but also, the near (the translator's mother tongue) is, as it were, distanced and made foreign". ${ }^{14}$ In fact, this exchange is the result of a joint effort in which the involvement of each participant is important only for quantitative research.

What is truly important is the fact that this dialogue, this process of exchange has created a community of translators and readers, a community which provides the playground for new ideologies, but which also contributes to the construction of a new paradigm, a linguistic oikumene, a restoration of the pre-Babel condition in a post-Babel world. Eugene A. Nida and Charles R. Taber, published the last volume, the eighth, titled The Theory and Practice of Translation, of a series dedicated to Bible translation, "Helps for Translators: Prepared Under the Auspices of the United Bible Societies". This scientific approach to translation starts from the assumption that, at the time of publication (1982) translation had given the world around 100,000 translators of secular and sacred texts, of whom around 3,000 were engaged in translating the Bible for $80 \%$ of the people on earth. ${ }^{15}$

The figures are impressive, or at least they were at the time, but what strikes the reader is the distinction Nida and Taber make between what they call the "old focus" (on form) and the "new focus" (on the response of the reader) in Bible/religious texts translation, stressing the fact that the "correctness" of the translated text should be analyzed in relation to the effect it produces on the intended target audience. For a translator and from a scientific

13 Hyang Lee, Seong-Woo Yun, "Ricoeur and Berman: An Encounter Between Hermeneutics and Translation Studies", in: Philosophy Today; Charlottesville, 56 (1/2012), p. 16-25, p. 17-18.

14 Antoine Berman, The Experience of the Foreign: Culture and Translation in Romantic Germany, trans. by S. Heyvaert, Albany, N.Y., State University of New York Press 1992, p. 99.

15 Eugene A. Nida, Charles R. Taber, The Theory and Practice of Translation, Helps for Translators: Prepared Under the Auspices of the United Bible Societies, VIII vols. Leiden, E. J. Brill for the United Bible Societies, 1982, vol. VIII, p. 1. 
point of view (Translation Studies is a science, after all), this is considered a truism today, but for a translator of a religious text, whether biblical or not, such an approach is relevant for several other reasons.

Beyond any technicalities attached to such a perspective, if we were to believe Nida and Taber, Bible translation has moved from a stage in which it was merely focused on reproducing, i.e. transferring the form of the message (read: "the Word of God") into a language of the gentiles, to one that closes the circle, and focuses on the reaction of the reader. This reaction should be tested against the "way in which the original receptors presumably reacted to the message when it was given in its original setting". Thus, benchmarking the translation process involves a new variable, one that gives the "correctness" a new dimension. A translation is correct if the receptor is "very unlikely to misunderstand it". ${ }^{16}$ In other words, the binomial source-text / target-text, extends to include the reaction of the community to the message, and the equals sign must be placed between the reaction of the original audience to the original text/message and the reaction of the new audience to the new (translated) text containing the old/original message.

This perspective implies that multiple, "correct" translations are not only possible but a sine qua non condition. This multiplicity, this heterogeneity of the "Word of God", suggests that the existence, or the alternation, of multiple forms of the Biblical text in the life cycle of the message it conveys is another step on the way to, if not a unity of faith, at least a unity of thought among Christian denominations. From the standpoint of Translation Studies, the many differences in form and style are just as many ways of starting and continuing the dialog.

Doing away with differences in terms of "correctness", or fidelity to the text and the message, is a lot easier than leveling the attitudes related to the hierarchy of languages, source or target. Source languages are sometimes given preeminence over the target languages, because of ignorance or failure to recognize "the genius" of each language and the fact that any message can be freed from its form and transferred into another language. This respect is the prerequisite for any dialog that would eventually make welcoming the other possible, and the only logical way to deal with the biblical text, for "[the] Bible is not a collection of cabalistic writings or of Delphic oracles. The writers of the Bible were addressing themselves to concrete historical situations and were speaking to living people confronted with pressing issues. It is not always possible for us to understand precisely what the writers

16 E. A. Nida, C. R. Taber, The Theory and Practice, p. 1. 
meant, but we do injustice to them to assume that they were intentionally trying to be obscure". ${ }^{17}$

In practice, this attitude translates into the unveiling of the true, original message of the source text, by giving it a new form in the target language and simultaneously preserving the content of that message. Returning to Berman and Ricoeur (see above), this is the "sacrifice" required by the process of welcoming the other, a sacrifice which involves both the source and the target language, both the original writer and the translator of the biblical text. This can be seen as an attack on identity, but an attack whose consequences are mitigated by the gain in equivalence, or, in other words, by recognizing and preserving the transcendence of the message in the transfer process.

Nida and Taber provide the translator with a few rules of thumb that should be observed in this transfer:

1. At all costs, the content of the message must be transferred with as little loss and distortion as possible. It is the referential, conceptual burden of the message that has the highest priority.

2. It is very important to convey as well as possible the connotation, the emotional flavor and impact, of the message. This is harder to describe than the first, and even harder to accomplish, but it is very important.

3. If, in transferring from one language to another the content and connotation of the message, one can also carry over something of the form, one should do so. But under no circumstances should the form be given priority over the aspects of the message. ${ }^{18}$

Therefore, easier said than done, the "new focus" of the (Bible) translation process is on the content of the message, on its connotation and on (at least) a fraction of its form, but not at the expense of the content: CONTENT-COnotation-(form). The entire process is organized around the importance of content, the bonding agent that turns the idea of multiple, equally "correct" or "good" translations possible. Testing a translation may follow a technical procedure (the test of dynamic equivalence, by comparison to "bad" translations involving formal correspondence or paraphrase) or the analysis of the receptor's reaction to the translated text: the full and facile comprehension of the original message and the personal involvement of the receptor, which might trigger a non-technical result of the testing process, i.e. the receptor's acknowledgement of the high quality of a translation: "I never knew before that God spoke my language". ${ }^{19}$

17 E. A. Nida, C. R. Taber, The Theory and Practice, p. 3-4, 7.

18 Ibidem, p. 118-19.

$19 \quad$ Ibidem, p. 173. 
Even though Nida and Taber's approach has its limitations and, to a certain extent, seem to contradict contemporary trends in Translation Studies, whose supporters argue in favor of a holistic approach to (Bible) translation, in which form and content, structure and function contribute to the meaning of the text, ${ }^{20}$ their The Theory and Practice of Translation is still relevant for translation scholars and translators working in the area of Bible translation. Moreover, some scholars divide the history of Translation Studies in the "era of dynamic equivalence" (Nida's era) and the "present era", or the era of contemporary translation theories, exposing the sins of the former, but also admitting that the "multi-disciplinary field" of translation studies has yet to produce "its Newton or Einstein" and hence a "a widely accepted, overarching, global translation theory, and perhaps never will." 21

Nevertheless, most of Nida's detractors fail to approach "dynamic equivalence" holistically, ignoring the other component parts of his theory:

In addition to proposing the term "dynamic equivalence" and defining it, [Nida's] Toward a Science of Translating more importantly establishes the elements that make up the mechanics of dynamic equivalence, namely, receptor response, functional classes of lexical symbols, "kernel" structures as a means of comparing languages, and the structure of translation as a process of decoding, transferring, and encoding.

[...] One is tempted at times to believe that people who read about or heard about dynamic equivalence after its introduction either ignored or did not understand the other elements of Nida's theory, and that this apparent fact has influenced the way in which dynamic equivalence was understood and applied. ${ }^{22}$

\section{Dynamic Equivalence versus (Essentially) Literal Translation in Bible Translation}

This involvement of multiple actors is not only possible at an end-user level, but it may also materialize in active participation in the translation process. The document Guiding Principles for Interconfessional Cooperation in Translating the Bible, ${ }^{23}$ originally published in 1968 , was revised and republished

\footnotetext{
20 See the Introduction to the first edition of Timothy Wilt (ed.), Bible Translation: Frames of Reference. Manchester, UK, Routledge 2002 (p. ix).

21 Aloo Osotsi Mojola, Ernst Wendland, "Scripture Translation in the Era of Translation Studies." in: T. Wilt (ed.), Bible Translation, 1-25.

22 Glenn J. Kerr, "Dynamic Equivalence and Its Daughters: Placing Bible Translation Theories in Their Historical Context" in: Journal of Translation 7, (1/2011), p. 1-19.

23 "Guiding Principles for Interconfessional Cooperation in Translating the Bible", in: The Holy See, 1987 <http:/www.vatican.va/roman_curia/pontifical_councils/chrstuni/general-
} 
in 1987 , only to restate the commitment to produce translations of the $\mathrm{Bi}$ ble that could eventually be considered acceptable by the members of all Christian communities. Obviously, the text of the Guidelines starts with the presentation of the Common Texts, i.e. the accepted source texts: the critical edition of the Greek New Testament and. The Biblia Hebraica Stuttgartensia, and continues with the description of the good practices in the translation of the Bible. The basic idea is that the entire process should comprise an entire community of people, from translators to members of the consultative group, all involved in the effort to produce the text to be published.

The text of the revised document published on the Vatican's website is preceded by a short Presentation issued by The Secretariat for Promoting Christian Unity and the United Bible Societies and signed by their representatives, Johannes Cardinal Willebrands (President, Secretariat for Promoting Christian Unity), Lord Donald Coggan (Honorary President, United Bible Societies), Pierre Duprey (Secretary), and Ulrich Fick (General Secretary), in which the authors state that the new document is to be called "Guidelines for Interconfessional Cooperation in Translating the Bible" (the previous version was titled "Guiding Principles for Interconfessional Cooperation in Translating the Bible").

The shift from "guiding principles" to "guidelines" seems important, especially in the context of publishing a new version, which contains minor changes "as a result of reports received from the users." The obvious intention is to provide a detailed set of rules to be used by the translators and reviewers working in "close cooperation" involved in the process of translating a Bible that "will be acceptable to, and be used by all Christians and Christian communities who speak the language into which the translation is being made."

There are two very important ideas related to this complex and tedious process: the fact that new text must satisfy the requirements of all Christian believers who speak a specific language and that language is the medium through which Christians may achieve their unity in confessing their faith: "The clear goal of this interconfessional effort is to produce editions of the Holy Scriptures which provide all speakers of the language with a common text. This will in turn make possible, often for the first time, a common witness to the Word of God in the world of today." Those engaged in this "interconfessional effort" should be organized as a professional translation team engaged in a rewarding, but also a challenging endeavor: a translation team, a review panel and a consultative group. According to the Guidelines..., the members of these groups must be of comparable qualifications, complemen-

docs/rc_pc_chrstuni_doc_19871116_guidelines-bible_en.html>, viewed on 2 November 2017. 
tary abilities, must respect one another and must be able to work together. Therefore, language (and translation) may bring a unity of faith for all Christians, a unity of faith based on the one Word of the One God.

Nevertheless, project management is just part of the process, the first and, probably, the most important step towards achieving a unique version of the Word of God in each language spoken today on earth for all Christians. The other steps which need to be taken are not facile at all. In most cases they could be regarded as merely technical issues, but they impact upon the common goal in multiple and unpredictable ways. Sometimes, these issues are related to terminology, to style or even to the actual practice of translation, to the methods that are most suitable in this case.

A long debate has been the one related to the best way to approach the source text, as it is actually the Word of God, it is the truth, inspired by the Holy Spirit. The battle between supporters of dynamic equivalence and those of (essentially) literal translation, has long been seen as a competition between the superiority of content over that of form in translating the Holy Bible. Such a perspective might seem too shallow to the bible translator who knows both sides and who understands that neither the former, nor the latter advocate radical approaches to the text. Nida and Taber ${ }^{24}$, for example, argue that content is the most important features of the text, but emotion and form (as much as possible) should be transferred to the target language. On the other hand, there are several charges against the essentially literal translation, which are superfluous and easy to prove wrong, especially because of the fact that they are too radical and they fail to address the real issue. The two divergent approaches are still relevant today in the field of Bible translation due to their (apparent) extremism which makes room for other (newer) translation theories and models that may contribute to a better understanding of the process and which attest to the fact that translation, in general, must be, first of all, multi-disciplinary.

Leland Ryken, in his article the "Five Myths About Essentially Literal Bible Translation", admitted he is a supporter of the essentially literal translation approach which he sees as the victim of the ruthless attack by supporters of dynamic equivalence. He identifies five charges which he calls "myths or fallacies" and debunks them one by one. Some of the arguments he uses in the process are indeed debatable, but there are several ideas in his introduction to the issue that could be very useful for somebody who would try to reconcile the two sides, and prove, after all, that language (read: translation) unites, since this is its first and most important function.

24 E. A. Nida, C. R. Taber, The Theory and Practice, p. 118-119. 
Firstly, Ryken defines his terminology by highlighting the difference between "essentially" and "totally." Thus,

essentially literal ... means that a translation strives to find the English word or combination of words that most accurately corresponds to the words of the original text. It does not mean translating the original in a way that makes no sense in English. Furthermore, retaining the syntax of the original, though not an irrelevant consideration, is nonetheless not a high priority, inasmuch as Hebrew and Greek syntax is so different from English syntax. ${ }^{25}$

In other words, essentially does not mean totally or completely, referring more to the substance rather than to the quantity and form of the message that is to be preserved in the target language text.

Secondly, he emphasizes that he has built a case for the essentially literal approach in translating the Bible into English, admitting to the fact that translations in other languages might generate a different debate and they represent a different case. ${ }^{26}$ According to Ryken, and this idea would be very hard to prove wrong, the principles of translation theory and practice should be adapted to the language pair involved.

The first charge against the literal translation of the Bible, or the first "myth", to use Ryken's word is that this non-conventional approach to Bible translation, as opposed to the mainstream dynamic equivalence approach is that those who support it are idolatrous worshippers of "word-for-word correspondence". In his attempt to debunk this first "myth", Ryken attacks the very father of dynamic equivalence, Eugene A. Nida, whose most important contribution to bible translation was, as he himself declared in an interview "to help people be willing to say what the text means-not what the words are, but what the text means" ${ }^{27}$ On a very superficial level, the dispute seems to involve the concept of priority, which Ryken brings to the battlefield as the weapon translation theorists love most. The translator must therefore make a clear-cut distinction between the two possibilities, namely to give priority to the audience (Nida and his followers, supporters of dynamic equivalence) or to the word (Ryken and the supporters of literal translation). Ryken admits that stating that Nida "made an idol of that audience"

25 Leland Ryken, "Five Myths About Essentially Literal Bible Translation", in: Translating Truth: The Case for Essentially Literal Bible Translation, Wheaton, Illinois, Crossway Books 2005, p. 57-76, p. 58.

26 Ibidem, p. 58.

27 David Neff, "Interview: Eugene Nida on Meaning-Full Translations", in: Christianity Today, 2002 http://www.christianitytoday.com/ct/2002/october7/2.46.html, viewed on 2 November 2017. 
would be just a "strange polemical maneuver", but, that, nevertheless, "as an advocate of linguistic conservatism", which means that "an English translation should preserve as much as possible of the very words of the original", his choice is based on the very words of the Holy Scripture, words that are inspired by the Holy Spirit (see Jer. 1.9; Jh. 6.63). ${ }^{28}$

Ryken is ready to accept differences of opinion, but he rejects any charges of idolatrous worshipping of the words of the Bible. He argues that the solution to this controversy can be found in humility, not in charges of idolatry. This view seems rather surprising, since it suggests humility might be the solution to a technical problem related to the theory and practice of translation. On the other hand, Nida does not even suggest that the form is not important. He agrees that the form is important, but it should not be given priority over meaning. In other words, the word of God is not just the signifier, but also the signified, the latter being the one that counts more. The importance of the signified is also the reason why people started to translate the Bible, otherwise the original versions of the Old and the New Testaments would have been enough for all Christian communities on earth, irrespective of the languages those communities might speak.

Another charge or, "myth" is the one that essentially literal translation theory and practice are naive. Of course, from a certain standpoint (that of the professional translator, or the scientist whose research focuses on translation studies), word-for-word translation is wrong, for many reasons which do not deserve further discussion here. Ryken's approach appears to be less technical, less "obscure", which is quite understandable given his approach to linguistics, a science that uses an excessively "technical and obscure ... vocabulary". If Ryken's statement that "the goal in Bible translation is truth" 29 is quite easy to accept, his rejection of the "technicalities" of a science such as linguistics is a lot harder to digest.

What Ryken identifies as maneuvers of dynamic equivalence translators resulting in biased and over-edited translations are nothing else but devices which produce the same effect as word-for-word or literal translations. His generalization that: "dynamic equivalence translations are actually hybrids, combining features of translation, a commentary, and a text edited to meet the translator's preferences for a given audience" ${ }^{30}$ is nothing but a description of a poor translating technique. Translation is not about imposing the translator's preference or meeting the audience's expectation. To paraphrase Nida and Taber (see above), translation is rendering the message

\footnotetext{
28 L. Ryken, "Five Myths About", p. 59-60.

29 Ibidem, p. 61.

30 Ibidem, p. 63.
} 
contained in a source-language text into a target language, by preserving as much as possible of its content and, we could add, form, but without focusing on form to the detriment of the content. This is a point where the two apparently controversial position can be reconciled, and Ryken admits it in a very short sentence: the goal of Bible translation "is meaning through or based on form". ${ }^{31}$

Therefore, what Ryken actually rejects is extremism in Bible translation, namely using dynamic equivalence at all costs, without the slightest interest in the form. The supporters of dynamic equivalence reject literal translation, performed as mere transcription/transliteration. Up to this point, it seems like the conclusion is obvious: the truth lies somewhere in between and the misunderstanding is, what the word itself actually means, the failure to comprehend the opponent's point of view. This takes us to the third "myth", that essentially literal translation is transcription, which Ryken quickly and reasonably debunks by using several examples taken from major English Bible translations.

The fourth "fallacy" is that advocates of essentially literal translators are not able to understand that translation is interpretation. In this case, Ryken's position would be easy to understand and accept even by the most stubborn supporters of dynamic equivalence: "essentially literal translations make a necessary distinction between linguistic or lexical interpretation and other types of interpretation, and refuse to add the activities of the exegete and the editor to the task of the translator". ${ }^{32}$ Concerning the fifth charge, the one related to the unreadability of essentially literal translations, the two parties should accept that the readability of a target text is not only tributary to the method employed in the process of translation, but it also depends on several other aspects.

Ryken's apology for essentially literal translation ends with a conclusion that, for the sake of reconciling the two approaches, may be reversed without any loss in terms of relevance and truthfulness: "essentially literal translation and practice are regularly misrepresented by devotees of dynamic equivalence". ${ }^{33}$ The solution to the controversy is provided by Nida's more balanced approach, described in his third rule of thumb for translators (see above): the form is important, but not in the absence of content; in other words, a good Bible translation preserves as much as possible of the form, but all of the content!

31 Ibidem, p. 69.

32 Ibidem, p. 76.

33 Ibidem, p. 76. 


\section{Conclusions}

In order to produce a usable and a living (one that would be able to become part of the Christian community and thus advance the process of creating a communality of faith) translation of the Bible, the translator must understand the paradox of translation, namely that of an equivalence which is only partially, or never fully adequate, as a relation between the source and the target text, as a continuous negotiation between means and purpose. The translator is the mediator who challenges the sacredness of the mother tongue, in an attempt to connect the author and the reader, by bringing them both in the same, common place. This work is similar to an effort of linguistic hospitality. Seen as a dialog, as an exchange, translation bridges gaps, creates communities, communities which might become part of a linguistic oikumene.

Translation, of sacred or profane texts, is a technical process which follows certain steps, its goal being to transfer the message contained in the source-language text into the target-language text. A unique source-language text may produce multiple "correct" translations, as a result of different perspectives upon the translation process, and the multiplicity of languages, as well as the differences between the context of the source as compared to that of the target-language text. Translation welcomes the other by liberating the message from its form and context and giving it the right to travel into a different home, a different language. The biblical message is thus transcendent: its only perfect code is the language of faith, which is unifying and able to bridge all gaps between Christian communities. Therefore, this perfect message is received in an imperfect language, but this transfer must be made as smooth as possible, so as not to distort the message and thus destroy its capacity to be understood.

This is the only possibility to reconcile the two, apparently, competing perspectives upon translation: dynamic equivalence and literal translation. The content of the message is given priority, but form must be as well preserved as much as possible in the transfer. Therefore, a linguistic oikumene is possible and may be achieved by making full use of linguistic hospitality, by receiving the other / the others (i.e., the foreign text, the text in a foreign language), by welcoming them into our own home (i.e., our own language, our own culture). 